\title{
Aconteceu, virou manchete
}

Ana Maria Ribeiro de Andrade José Leandro Rocha Cardoso

Museu de Astronomia e Ciências Afins

RESUMO

Na década de 1950, não havia no Brasil revistas especializadas em divulgação da ciência. O rádio era o principal meio de comunicação de massas. Considerando que a fraca articulação entre ciência e sociedade tem raízes históricas, este trabalho analisa como a Manchete - revista semanal de entretenimento e fatos diversos - apresentava a ciência a seus leitores. Primeiramente, são analisadas as características editoriais da Manchete e as informações sobre a freqüência e as particularidades das matérias publicadas sobre ciência e tecnologia. Depois, fazendo um paralelo com a revista $O$ Cruzeiro, o trabalho destaca a contribuição da Manchete para o desenvolvimento do pensamento científico.

Palavras-chave: divulgação da ciência; Manchete; 0 Cruzeiro.

\section{ABSTRACT}

In the 50's the science press for the general public was almost absent in Brazil. Radio broadcast was the main channel for mass communication. Considering that weak articulation of science and society has historical roots this work examines how the variety and entertainment weekly magazine Manchete presented science to its readers. In a first approach the editorial practice, characteristics and the frequency of science and technology news in Manchete is analyzed compared to the magazine 0 Cruzeiro, showing the contribution of Manchete to the development of scientific thought. Key-words: public understanding of science; Manchete; O Cruzeiro. 
Nos últimos séculos, a ciência vem disputando a hegemonia com outros saberes, práticas e poderes. Os avanços científicos, as inovações técnicas e os artefatos bélicos relacionados com as grandes guerras na Europa do século XX favoreceram a ciência, garantindo-lhe um lugar privilegiado na sociedade. A configuração da Guerra Fria fez da ciência e da tecnologia o baluarte da disputa entre os Estados Unidos e a União Soviética, evidenciado pela corrida espacial. O temor do lançamento de uma terceira bomba atômica corroborava para assegurar a supremacia da ciência sobre as demais crenças e formas de conhecimento. A acirrada polarização entre países capitalistas e socialistas, fomentada pelas duas grandes potências da época, EUA e URSS, beneficiou sobremaneira o desenvolvimento da pesquisa científica nos países alinhados a esses blocos ideológicos. Se foram criados com êxito grandes laboratórios nacionais sabe-se hoje, que atrocidades foram cometidas sob o discurso da autoridade científica. O radium, por exemplo, era propagado na imprensa como um elixir, não dos deuses, mas da ciência, antes que se conhecesse as suas conseqüências funestas. A ficção científica também teve lugar especial. Os discos-voadores e a energia nuclear eram os principais temas das produções cinematográficas, da literatura de ciência e ficção e de reporta24 gens sensacionalistas nos meios de comunicação. Naquela conjuntura, não só os sucessos da ciência e da tecnologia garantiam o poder e a supremacia dos países, mas também a publicidade em torno dos mesmos.

No Brasil, cuja situação de subdesenvolvimento não lhe conferia uma posição independente na conjuntura política internacional, a ciência ganhou contornos particulares, apesar das dificuldades de articulação com a sociedade. Por um lado, o projeto desenvolvimentista implementava um modelo de industrialização dependente tecnologicamente e atrelado à divisão internacional do trabalho. Do outro lado, a mentalidade conservadora que predominava no meio universitário, no qual ainda prevalecia a visão utilitarista da ciência, o bacharelismo e resíduos do modelo politécnico, obstava o desenvolvimento da pesquisa científica ${ }^{1}$. Mesmo assim houve grandes vitórias da comunidade de professores e pesquisadores: criação de institutos de pesquisa - Instituto de Biofísica (1945), Centro Brasileiro de Pesquisas Físicas (1949), Instituto Nacional de Pesquisas Amazônicas e o Instituto de Matemática Pura e Aplicada (1952); institucionalização de disciplinas científicas; profissionalização dos cientistas; participação do Estado no fomento da ciência, por meio da criação do CNPq (1951) e da Capes (1952); organização da Sociedade Brasileira para o Progresso da Ciência; aumento da produção científica e 
publicação de importantes trabalhos em biologia, agronomia, física e matemática; construção de sólidas alianças entre cientistas e militares; êxitos de brasileiros em laboratórios estrangeiros; e, também, desafios, fracassos e até escândalo de corrupção no mundo da ciência ${ }^{2}$. Assim, físicos, astrônomos, biólogos, professores, engenheiros e militares, ao lado de misses, atrizes, políticos e vedetes, fizeram parte do retrato construído pelo imaginário coletivo da sociedade urbana brasileira, a partir das fotografias publicadas nas revistas 0 Cruzeiro e Manchete.

A partir dessas observações, surge o interesse em analisar a revista Manchete-o principal veículo de comunicação da Empresa Bloch, até meados de 2000 - ou de identificar como a revista divulgava a ciência para leitores leigos e pouco familiarizados com a atividade científica e tecnológica, e que viviam em um país distante dos chamados centros produtores de ciência. Este trabalho objetiva inferir se essa revista contribuiu positivamente para a formação de uma mentalidade científica - tentando obter informações que permitam compreender determinados comportamentos sociais em relação à ciência e tecnologia - e comparar os resultados obtidos anteriormente no exame de 0 Cruzeiro ${ }^{3}$. Não porque tenham sido revistas especializadas em divulgação científica mas, ao contrário, porque foram revistas semanais de fatos diversos, de grande tiragem e de circulação nacional, que publicavam reportagens alusivas à ciência, entre as seções dedicadas à arte, à política, aos esportes e a temas de interesse feminino.

Muito embora não seja possível precisar exatamente a penetração social, tudo indica que essas matérias atingiam as classes alta e média. Logo, a capacidade de apreensão direta do conhecimento científico era restrita. Contudo, o estudo da Manchete poderá fornecer novos indicadores para a compreensão da fraca articulação entre ciência e sociedade e para a análise do processo de formação de uma mentalidade científica.

O levantamento de dados em mais de 500 edições da revista Manchete (1952-62) foi realizado na biblioteca da ABI (Associação Brasileira de Imprensa) e no arquivo da própria Manchete, ambos sediados na cidade do Rio de Janeiro. Nessa etapa da pesquisa histórica, o critério utilizado foi a seleção de reportagens, títulos e notas alusivas às áreas tradicionais da história da ciência: ciências biológicas e da saúde, ciências da terra e da natureza, e engenharias. Ao mesmo tempo, procurou-se recuperar informações sobre o público leitor, a tiragem, a linha editorial e a história da revista.

Em suma, o trabalho apresenta as características e a política edito- 
rial da revista Manchete; quantifica e analisa informações e, finalmente, compara a Manchete com 0 Cruzeiro. Conclui que a Manchete - diferente de 0 Cruzeiro - pode ter contribuído para estimular o desenvolvimento dos pensamentos científico e filosófico no Brasil naqueles anos.

\section{A DIVULGAÇÃO DA CIÊNCIA}

Mesmo no Brasil dos anos 50 - de imensa maioria analfabeta ou semi-analfabeta de origem rural, cuja atividade científica praticamente estava restrita a poucas instituições do Rio de Janeiro e São Paulo - já havia interesse pelos avanços da ciência e da tecnologia. Novidades tecnológicas, especialmente eletrodomésticos, automóveis, medicamentos, implementos e máquinas agrícolas, chegavam ao incipiente mercado consumidor brasileiro. Onde havia eletricidade, podiam ser encontrados em residências de famílias abastadas: geladeiras, enceradeiras, liquidificadores e ferros elétricos. Automóveis e caminhões importados trafegavam pelas ruas de cidades tradicionais, ao lado de veículos de tração animal. Tratores de fabricação americana eram oferecidos a promissores compradores da agroindústria açucareira dos Estados de São Paulo e Pernambuco. Viagens aéreas, sem escala, entre o Rio de Janeiro e Porto Alegre, começavam a ser anunciadas em aviões super-convair. Se já naqueles anos a maior parte da população urbana brasileira era do sexo feminino - inversamente à população rural -, o público alvo da publicidade impressa eram os homens. O rádio, entretanto, era o principal meio de comunicação de massa e atingia indistintamente homens e mulheres de diferentes classes sociais. Apenas o rádio garantia à notícia atualidade, impacto e abrangência nacional. A televisão apenas começava a ser transmitida nas principais capitais, e os grandes jornais da então capital federal, o Rio de Janeiro, chegavam ao interior com atraso de muitos dias, transportados pelas velhas locomotivas a vapor. Eram lidos pelo seleto grupo composto por profissionais liberais, funcionários do Estado, proprietários e comerciantes ilustrados. Logo, prestavam-se à informação e à reflexão de uma minoria de pessoas alfabetizadas e, preferencialmente, do sexo masculino, pois os cursos superior e técnico também eram privilégio dos homens das classes sociais alta e média. As mulheres dessas classes sociais faziam curso de formação em educação primária, e um insignificante percentual seguia cursos nas faculdades de filosofia e ciências humanas. Era raro encontrar uma mulher nos cursos de medicina, engenharia e ciências.

O Cruzeiro foi a primeira revista de circulação nacional de fatos diversos a introduzir a linguagem da fotorreportagem. Criado em 1928 e 
reformulado em 1945, esse periódico revolucionou a técnica e o espírito do jornalismo ao romper com a influência das escolas européias na imprensa brasileira. Dominou esse mercado por algumas décadas, uma vez que possuía uma excelente rede de distribuição. Por ser uma revista semanal de entretenimento, com muitas fotografias e títulos, representava a possibilidade de mais pessoas de uma mesma família, principalmente as mulheres, lerem ou folhearem as suas páginas de diversas maneiras. Sua linha editorial era precisa: queria ser popular a fim de fazer-se compreender por todos e para vulgarizar as artes e as ciências. Por isso, a pauta entremeava fatos verossímeis entre trivialidades de aceitação garantida. As fotografias imprimiam o realismo. De inegável qualidade técnica, as fotografias não se limitavam a uma página; estendiam-se à página do lado, deixando o leitor embevecido pela imagem ${ }^{4}$.

A partir de 1952, a revista Manchete tornou-se a principal concorrente de 0 Cruzeiro. Ambas, afora serem publicadas na cidade do Rio de Janeiro, recorriam à linguagem do fotojornalismo, incluindo em todos os números bem elaboradas fotorreportagens, tal como a Life e a Paris Match o faziam. Não por coincidência, o processo de decadência de 0 Cruzeiro se iniciou quando a Manchete, em meados dessa década, contratou jornalistas que se demitiram da revista concorrente e aprimorou a qualidade gráfica para ficar cada vez mais colorida, atraente e fácil de ler. Eram as condições exigidas para manter e conquistar mais leitores. Dado que o público leitor só podia ser definido experimentalmente, os editores levavam em consideração o fascínio que o assunto da capa da revista exercia sobre os leitores ou a aptidão dos leitores para receber as informações divulgadas pela revista. Ajustava-se a revista ao interesse e à capacidade de percepção do receptor da informação. Detendo o poder de controlar a informação e formar opinião, a imprensa é porta-voz dos interesses de determinados grupos sociais.

Dado o papel dos meios de comunicação de massa na sociedade, a divulgação da ciência tornou-se tema de reflexão e análise de jornalistas, de especialistas da área da educação, de ciências sociais e dos próprios cientistas, além de atrair a atenção de historiadores da ciência. Tema de monografias e teses de pós-graduação dos primeiros ${ }^{5}$, esses trabalhos procuram avaliar a qualidade da informação veiculada, mensurar os temas e avaliar a freqüência dos assuntos abordados, a disposição das matérias e a predisposição do público leitor, suas características, o trabalho do jornalista, a importância da ilustração, e o resultado final da editoração. Mas, enquanto jornalistas e educadores se detêm, em particular, no exame da linguagem e dos aspectos relacionados à leitura, aos historiadores 
interessa sobremaneira analisar a contribuição dos meios de comunicação social na formação da mentalidade e da cultura científica.

A divulgação da ciência ou a direção do trabalho do cientista na sociedade são aqui consideradas como partes de um horizonte ou categoria que representa um dos planos de ação de atores sociais. Seria como uma ramificação do trabalho do cientista, a prestação de contas ou a socialização do conhecimento produzido no laboratório, em que os resultados de uma investigação são comunicados à sociedade por meio do discurso jornalístico. Tem a função de despertar o interesse pela ciência, com vistas à alfabetização científica ${ }^{6}$ e para a obtenção do apoio necessário ao desenvolvimento de projetos de pesquisa. Um movimento nem sempre ajustado aos anseios da sociedade, seja porque, por deficiências do sistema educacional, a compreensão da prática científica está fora do alcance da maioria da população, ou porque existam problemas de tradução dos resultados científicos para o texto jornalístico.

$\mathrm{Na}$ perspectiva da História Social da Ciência, a análise da divulgação da ciência leva à reflexão sobre a intermediação do jornalista e os conflitos decorrentes da tradução de práticas discursivas. $\mathrm{O}$ discurso científico e o discurso jornalístico por vezes entram em choque porque, nessa tradução, ambos aportam características de campos distintos. Por um lado, o reconhecimento do cientista no seu campo de lutas - o campo científico - confere ao mesmo autoridade para divulgar externamente resultados científicos. Do outro, o campo jornalístico - específico em sua atividade por exercer o poder de controle da informação - baseia-se em um conjunto de pressupostos e crenças, mas detém poderes especiais na intermediação do campo científico com outros campos que lhe são alheios. O monopólio real dos meios de comunicação, inclusive sobre a divulgação científica em grande escala, controla tanto o acesso à informação dos cidadãos comuns como tem instrumentos para interceptar outros produtores culturais, cientistas, escritores... A notoriedade pública, fundamental para o cientista reproduzir o capital simbólico, é controlada pelo campo jornalístico que, pelo mesmo poder, submete o discurso científico ao princípio da seleção que os jornalistas operam na realidade social ${ }^{7}$.

No caso brasileiro, a divulgação científica tem particularidades. De um lado, porque nunca houve grandes investimentos em ciência e tecnologia ou programas de governos que efetivamente privilegiassem o seu desenvolvimento no país. De outro, porque tampouco a educação em ciência é capaz de atingir a população em percentuais significativos, devido a fatores relacionados com a esfera política, com o sistema educacional (deficiências dos currículos escolares, da formação do corpo docente etc.), com a carência de instituições de educação não formal (museus 
e centros de ciência) e com o próprio campo jornalístico. Nesse contexto, os meios de comunicação cumprem a função de apresentar a ciência para a população, cujo índice de alfabetização científica é baixo. A imprensa, o rádio e, nas últimas décadas, a televisão são os principais canais de divulgação científica para os brasileiros: introduzem noções e conceitos científicos, prestam informações relativas à produção científica, apresentam instituições de pesquisa ao explicar suas atribuições, põem em evidência e dão a conhecer cientistas das áreas mais organizadas ou de maior repercussão na sociedade, enfim, fornecem indicadores de como a ciência é feita. Como é pequeno o número de profissionais especializados em jornalismo científico, vigora o senso comum e reforçam-se mitos, estigmas e estereótipos.

A despeito dos esforços individuais, o sensacionalismo é a principal característica da divulgação da ciência no Brasil. Na tradução dos divulgadores, a construção dos fatos científicos é sempre envolta em mistérios, a genialidade está presente em todas as descobertas e a História está quase sempre ausente. A ação da ciência, as controvérsias filosóficas e científicas, as representações da natureza nos laboratórios, a disputa entre colegas, o processo de validação dos fatos científicos, as redes de cientistas, as dificuldades e fracassos, por exemplo, nem ficam subentendidos. O filtro do discurso jornalístico exclui as agruras da produção da ciência, forja mentalidades, pasteuriza a informação para atingir o grande público.

Se atualmente há revistas especializadas em divulgar a ciência e suas aplicações - i.e., Ciência Hoje e Galileo -, além de programas na televisão e seções especializadas nos grandes jornais diários, os temas preferidos estão relacionados com as ciências biológicas e da saúde (leia-se: em especial reportagens financiadas pelas indústrias química, farmacêutica e de bioengenharia), com os sucessos dos programas espaciais dos países do centro produtor de tecnociência e com as grandes descobertas que causam impacto e são manchete. Nos anos 50, se não havia periódicos especializados em divulgação científica, entretanto, os resultados são semelhantes (Quadro 1). Excepcionalmente, os grandes jornais publicavam encartes sobre ciência. Notas sobre eventos científicos, descobertas científicas, inaugurações e posse de diretores de instituições eram os assuntos mais comuns nos registros jornalísticos. Revistas de instituições científicas desempenhavam essa função no âmbito da área de sua atuação, como a revista do Observatório Nacional. Diferente de hoje, ciência e tecnologia faziam parte do cotidiano de poucos brasileiros. O acesso à tecnologia marcava a diferença social: os eletrodomésticos e automóveis eram símbolo do status das classes privilegiadas e do modo de vida cos- 
mopolita. Noutra esfera e em outros continentes, os satélites funcionavam como troféus do progresso científico e tecnológico das nações desenvolvidas num mundo dividido entre países ricos e pobres, capitalistas e socialistas, avançados e atrasados, desenvolvidos e subdesenvolvidos, e centrais e periféricos.

\section{A HISTÓRIA DA MANCHETE}

A Manchete começou a circular em abril de 1952, um ano depois de Adolpho Bloch ter apresentado o projeto de criação de uma revista a Henrique Pongetti e Raimundo Magalhães Júnior, amigos intelectuais, e a Pedro Bloch, primo e médico foniatra. Imigrante russo naturalizado brasileiro que aqui chegou com a família em 1922, Adolpho Bloch apostava que havia lugar no mercado para mais uma revista de circulação nacional, ou seja, que poderia concorrer com 0 Cruzeiro. Com base na experiência adquirida nas tipografias da família - na antiga URSS, em Jitomir e Kiev, e no Rio de Janeiro - alicerçava-se nas possibilidades de introduzir inovações editoriais na publicação e aprimoramentos técnicos no equipamento gráfico para vencer o desafio de concorrer com $\mathrm{O} C r u$ zeiro. $\mathrm{O}$ investimento inicial foi pequeno e o custo de produção era baixo: as máquinas da tipografia da família, ficando ociosas três dias na semana, podiam imprimir edições semanais da Manchete de 200 mil exemplares. Ainda assim, a revista custava o mesmo preço da principal concorrente.

A lucratividade da empresa era surpreendente. Em poucos anos, a Manchete ocupava um prédio próprio na Rua Frei Caneca, no bairro da Lapa, que fica próximo do centro e onde estavam instalados vários jornais e a revista $O$ Cruzeiro. Foram adquiridas máquinas para imprimir 800 mil exemplares semanais e um terreno no subúrbio de Parada de Lucas, onde se construiu o parque gráfico. Inversamente à estratégia de 0 Cruzeiro de alardear tiragens inacreditáveis, a Manchete não revelava essa informação. A estimativa só pôde ser feita com base no relato de Adolpho Bloch sobre a capacidade das rotativas ${ }^{8}$.

$\mathrm{O}$ investimento em equipamentos e instalações foi simultâneo à reformulação da política editorial de 1956. A mudança abrangeu todos os setores da publicação, transformando a paginação e atualizando o texto, com o objetivo de fornecer ao leitor elementos necessários à compreensão dos acontecimentos. A equipe de redação foi reforçada. Do quadro de jornalistas, redatores e colaboradores - selecionados entre pessoas de destaque no meio intelectual - fizeram parte Carlos Drummond de Andrade, Rubem Braga, Joel Silveira, Orígenes Lessa, Raimundo Magalhães 
Júnior, Guilherme Figueiredo, Otto Maria Carpeaux, Manuel Bandeira, Fernando Sabino, Antônio Maria, Nelson Rodrigues, Marques Rebello, Paulo Mendes Campos, Lígia Fagundes Telles, Antônio Callado, Sérgio Porto, Ciro dos Anjos, Olegário Mariano, Jânio de Freitas e muitos outros. Jean Manzon, que trabalhou para a Paris Match e 0 Cruzeiro, foi o principal fotógrafo. Ao seu lado, estiveram Darwin Brandão, Gil Pinheiro, Gervásio Baptista, Fúlvio Roiter, Jader Neves etc.

O primeiro número da Manchete estampava na capa uma bailarina do Theatro Municipal do Rio de Janeiro, e alardeava como exclusividades "Uma grande reportagem de Jean Manzon" e "A verdadeira vida amorosa de Ingrid Bergman". O fundo escuro, contrastando com o dourado de uma carruagem que servia de cenário e com as chamadas emolduradas em vermelho, desagradou ao próprio Bloch'. A revista era pouco atraente: papel de qualidade inferior, diagramação ruim, e a matéria de capa era a única colorida.

Por volta de 1956, com a aquisição de novas impressoras, o padrão gráfico ganhou qualidade. Nahum Sirotsky, que sucedeu a Henrique Pongetti no cargo de editor geral, foi o responsável pelas mudanças. O sucesso ele creditou ao grupo formado por Alberto Dines, Darwin Brandão, Newton Carlos, desenhistas, técnicos e gerentes. O apogeu da Manchete coincidiu com o declínio de 0 Cruzeiro ${ }^{10}$ e com a transferência de dezessete jornalistas deste periódico para a Manchete, em 1958, por divergirem da postura ética do proprietário.

Politicamente, a revista se identificava com a corrente desenvolvimentista antiliberal e industrializante ${ }^{11}$ do pensamento econômico. Adolpho Bloch era amigo e dedicava irrestrito apoio ao governo Juscelino Kubitschek, desde a campanha eleitoral. É de sua autoria o slogan "50 anos em 5", muito embora a sua revista fizesse críticas à política de saúde e educação. Antes dele, João Alberto Lins de Barros foi outro político que teve espaço na publicação. Já $O$ Cruzeiro pendia sempre para posições ideológicas conservadoras - próximas da corrente do pensamento denominada neoliberal -, alimentando verdadeira aversão aos monopólios de Estado, a pretexto de salvaguardar os interesses dos capitais privados nacionais e estrangeiros. Desse modo, Getúlio Vargas era execrado, bem como João Alberto, seu antigo colaborador e presidente do Centro Brasileiro de Pesquisas Físicas.

\section{A CIÊNCIA EM MANCHETE}

$\mathrm{Na}$ Manchete não havia uma seção dedicada à ciência - como existia para política, comportamento, cinema, teatro, culinária e outras tantas 
assinadas - nem tampouco era especializada no assunto. Ciência e tecnologia foram temas de fotorreportagens exclusivas, bem como apareciam em pequenas notas ou nas seções consagradas: "O Brasil em Manchete", "O mundo em Manchete", "O leitor em Manchete", "Notícias que valem Manchete", "Manchetinhas" e "Posto de Escuta". Ainda que nessas seções predominassem notícias sobre concursos e viagens de misses, catástrofes, política e economia, astros e estrelas do cinema e do teatro, há registros da passagem de algum cientista famoso pelo Brasil e de acontecimentos relevantes no campo da ciência. As notícias referiam-se mais a acontecimentos científicos que tiveram lugar em países estrangeiros $(58 \%)$ do que à incipiente produção científica do país (42\%). A disparidade não parece ser tão grande, porque há muitas matérias sobre aplicações da ciência na área da saúde pública.

Os editoriais do período 1952-62 não faziam referência à ciência. O editorial publicado em 5 de fevereiro de $1955^{12}$, assinado por Henrique Pongetti e intitulado "Ratos no ciclotron" - o desfalque no Projeto dos Sincrociclotrons ${ }^{13}$-, foi uma exceção. Porém, a tônica não era o problema da corrupção, o "caso Difini”, mas a ameaça que o físico brasileiro Cesar Lattes teria feito de encerrar a sua carreira científica caso o culpado não fosse punido. Apelos emocionados, enumerando as dificuldades financeiras enfrentadas pelo CBPF (Centro Brasileiro de Pesquisas Físicas) e comparando as carreiras científicas de Lattes e Enrico Fermi caracterizam a opinião da revista.

Num estilo próprio, a revista apropriou-se da linguagem e do discurso do fotojornalismo. As fotografias ocupavam em média $70 \%$ das páginas nas fotorreportagens, mas chegavam a ocupar páginas inteiras. Os textos e legendas preenchiam as lacunas entre títulos e subtítulos, fotografias, gráficos, desenhos e quadros que eram inseridos para facilitar a compreensão dos leitores. No estilo literário da época e com um português primoroso, a linguagem dos textos era quase poética e se inspirava na fotografia principal da matéria. Sem perder de vista o caráter informativo e quase didático, as matérias traziam informações sobre a confirmação de fatos científicos e sobre novos artefatos e processos tecnológicos, tais como: medicamentos, vacinas e tratamentos de doenças; biografia de cientistas; atividades de pesquisadores de disciplinas emergentes; avanços tecnocientíficos; inauguração de institutos, laboratórios e instrumentos de pesquisa; congressos científicos e questões de saúde pública. Neste caso, há informações sobre a controvérsia de tratamentos e confronto de opiniões, mas não há nada à respeito das controvérsias de cientistas em seu campo de ação. Estas raramente ultrapassam os domínios exclusivos 
da ciência, permanecendo na esfera de atuação do laboratório, onde a ciência tem autonomia.

A imagem fotográfica é uma forma particular de comunicação: imagens e texto se complementavam. Ao flagrar acontecimentos, selecionar momentos singulares e registrar o cotidiano, ela provoca de imediato algum tipo de emoção no leitor, podendo ser captada como realidade. A imagem fotográfica encurtava os caminhos da leitura e facilitava a apreensão de informações, haja vista o impacto causado pelas primeiras fotografias de guerra publicadas na imprensa, no início do século XX, e a repercussão das imagens entre civis que nunca haviam estado em um front $^{14}$. A primeira vista, o discurso de apropriação estética empresta verossimilhança à informação, ampliando a credibilidade do tema abordado e reforçando a confiabilidade no veículo de comunicação. Folheando um exemplar da Manchete, mesmo os analfabetos teriam sido capazes de apreender informações sobre o Sputnik, a criação da Petrobras, a bomba atômica, a vitória no tênis de Maria Esther Bueno, a morte de Getúlio Vargas, etc. Poderiam ainda conferir o luxo de fantasias do carnaval do Rio de Janeiro e deliciar-se com fotos de Sacha Distel e Brigitte Bardot.

A análise dos textos de divulgação científica leva em consideração, além da política editorial, a ética, a fidedignidade das informações, as opções de linguagem e os cuidados na transposição do discurso científico para o discurso jornalístico ${ }^{15}$. Afora o jornalismo científico não ser uma especialidade nos anos 50, cientistas e jornalistas brasileiros pertenciam ao mesmo grupo social, freqüentando os mesmos ambientes. Mesclavamse no meio intelectual e na imprensa o cientista estava no mesmo patamar de outras personalidades públicas (políticos, bispos, rainhas, intelectuais, atrizes e jogadores de futebol). Cientistas brasileiros, cujas contribuições passariam à história da ciência, eram tão poucos que não ficavam no anonimato. Não eram, como hoje, integrantes ou coordenadores de grupos de pesquisa experimental e co-autores de trabalhos assinados com dezenas de colegas. Eles próprios, como recorda José Leite Lopes, interferiam na construção da imagem da ciência, visando estreitar o relacionamento cientista-jornalista-público e abreviar o tempo da comunicação. Contrastando com a tendência atual, contribuíam o fato das matérias se centrarem na personalidade e a maior mobilização política dos cientistas.

Cientistas foram capa da Manchete e assunto de chamadas - frases curtas, de efeito e sem rigor na pontuação sobrepostas à fotografia -, o que revelava prestígio na sociedade e, também, que a revista valorizava a atividade científica. Sobremaneira, as imagens de capa mais recorrentes foram as misses, atrizes, vedetes, bailarinas e modelos. Em média, a cada 
seis capas destacando a mulher, um político era o personagem eleito. Dentre os outros temas contemplados na capa estão a cultura popular (Rei Momo e Papai Noel), moda e crianças.

$\mathrm{Na}$ edição da semana de 31 de maio de 1952, a capa era uma foto do Instituto de Manguinhos com a chamada "Manguinhos não é uma torre de marfim.” Na semana seguinte, era um cientista ao microscópio e a frase: "Um milhão de cruzeiros por um mosquito." No primeiro número, havia duas matérias sobre ciência. Uma, tratava do dia-a-dia dos cientistas de Manguinhos: condições de trabalho; infra-estrutura; pesquisas em andamento; produção de vacinas; registrava que os cientistas recebiam salários de Cr\$3.700,00, e trazia ainda fotografias de Walter Oswaldo Cruz, Olympio da Fonseca, Cassio Miranda, Nogueira Penido, Paulo Muniz e Miguel Ozório. A outra matéria, em cores, apresentava o entomologista Ferreira d'Almeida - dono de coleção de mais de vinte mil borboletas que, depois de ser carteiro, tornara-se "naturalista auxiliar" do Museu Nacional. Já no número seguinte, em junho, a reportagem de capa tratava da malária - do mosquito transmissor, regiões mais afetadas, número de mortes -, enfatizando a carreira do sanitarista Manuel Ferreira no Serviço Especial de Saúde Pública e na Faculdade Fluminense de Medicina. Publicou-se, ainda no mesmo número, uma reportagem intitulada "Vinte parlamentares médicos à cabeceira do Brasil", com a fotografia 3 x 4 e a identificação do partido político de cada médico que passou à política. Em junho, a revista ainda tratou de questões decorrentes da aplicação da física, da bomba atômica ${ }^{16}$.

Era evidente o empenho da Manchete na divulgação da ciência, no ano em que começou a circular. Em dois números do mês de julho foram publicadas reportagens sobre ciência ou aplicações da ciência: "A medicina progride. Novas aplicações da eletroterapia"; e "Físicos discutem física”, com fotografias de Álvaro Alberto, Arthur Moses, José Leite Lopes e outros no Simpósio sobre Novas Técnicas da Física. O mesmo aconteceu em agosto de 1952 nas reportagens: "As esposas falam de seus maridos famosos" - Martha Lattes ressaltou os hobbies de Cesar Lattes; e "A luta contra a dor. Agora temos a hipo-anestesia. Não se sente e não se vê a broca" 17 .

O resultado da classificação das reportagens e notas por área do conhecimento confirma a predominância das matérias sobre saúde e biologia, embora tenham sido apresentadas em separado (Quadro 1). Certamente, a prática médica é o assunto de maior apelo no cotidiano das pessoas. A engenharia, por causa das matérias sobre satélites e corrida espacial, aparece em segundo lugar. Sobre a física - então a ciência de fronteira - as matérias estavam vinculadas ao contexto da Guerra Fria e ao 
uso pacífico da "energia dos átomos”. As fotografias eram enormes e sempre acompanhadas de legendas explicativas.

No início da década de 1950, o desenvolvimento das pesquisas sobre a poliomielite e o aumento do número de crianças contagiadas se reflete nos resultados do Quadro 1, nas colunas saúde e biologia. Não obstante a interferência de fatores relacionados à produção científica e a freqüência dos assuntos abordados não apresentar mudanças significativas, no período da reformulação editorial da Manchete (1956) o foco se transfere dos cientistas de maior projeção social para a divulgação das grandes pesquisas científicas, a big science.

À medida que o tempo passava e aumentava a experiências dos editores, Manchete se tornava mais superficial para agradar a mais leitores. Quando se tratava de médicos, valorizava-se o grande especialista, as viagens dos mesmos para congressos eram noticiadas no "Posto de Escuta", e os diretores de hospitais eram citados nominalmente. Aparentemente, havia matéria paga sob o véu de história de instituições médicas ou troca de favores. Neuroses, enfarto e câncer eram consideradas "as três pragas do século" ${ }^{18}$.

Quadro 1 - A ciência na Manchete. (1952-62)

\begin{tabular}{|c|c|c|c|c|c|c|c|}
\hline ANO & SAÚDE & ENGENHARIA $^{1}$ & FÍSICA & BIOLOGIA & ASTRONOMIA & OUTROS $^{2}$ & TOTAL \\
\hline 1952 & 7 & 1 & 3 & 3 & & 2 & 16 \\
\hline 1953 & 13 & & 3 & & 1 & & 17 \\
\hline 1954 & 11 & 1 & 6 & 4 & & 3 & 25 \\
\hline 1955 & 11 & 3 & 14 & 10 & 1 & & 39 \\
\hline 1956 & 14 & 2 & 8 & 9 & 1 & 1 & 35 \\
\hline 1957 & 11 & 15 & 7 & 6 & 1 & 4 & 46 \\
\hline 1958 & 11 & 25 & 18 & 8 & 1 & 2 & 65 \\
\hline 1959 & 8 & 17 & 7 & 3 & 2 & 3 & 40 \\
\hline 1960 & 4 & 9 & 6 & 6 & 3 & 1 & 29 \\
\hline 1961 & 17 & 30 & 8 & 1 & 3 & 1 & 60 \\
\hline 1962 & 16 & 19 & 6 & 5 & 3 & & 49 \\
\hline Total & 123 & 122 & 86 & 55 & 18 & 17 & 421 \\
\hline$\%$ & 29 & 29 & 20 & 13 & 5 & 4 & 100 \\
\hline
\end{tabular}

Observações: 1. Inclui as matérias sobre engenharia aeroespacial, tecnologia de armamentos e engenheiros; 2. Inclui as matérias sobre química, meteorologia, arquitetura, etc., que aparecem com pouca freqüência.

Fonte: Manchete. Rio de Janeiro, 1952-62. 
Dois assuntos destacados pela revista tinham grande repercussão na época: a utilização da energia nuclear - devido às discussões sobre o seu uso pacífico, a bomba atômica e a exploração das reservas nacionais de minerais radioativos -, e os programas espaciais soviéticos e americanos. A partir de 1958, foi grande o número de leitores que escreveram para a revista a respeito desses assuntos. O lançamento do Sputnik, em outubro de 1957, incitou sobremaneira o imaginário popular já povoado pela possibilidade de vida extraterrestre, discos-voadores e por heróis do espaço. O russo Yuri Gagárin, o primeiro cosmonauta, protagonizou fotorreportagens de várias páginas da revista, principalmente em sua passagem pelo Brasil. Seu nome e sua imagem correram o mundo e até hoje é citado pela mídia. Virou marca de cigarro na URSS e, no Brasil, inspirou a mãe de Yuri Gagárin da Silva ${ }^{19}$.

Em "O leitor em Manchete" - seção na qual a revista mantinha um canal aberto com o público leitor - uma carta com o título "Astronáutica russa" é elucidativa:

Algo está destoando na sua revista: o modo como vêm sendo divulgadas as façanhas científicas da URSS e o total desprezo pelos feitos dos EUA, nossos aliados naturais. Enquanto os americanos lançam 28 satélites de comprovado valor científico, cujos resultados são postos à disposição do mundo, a Manchete tem cuidado de publicar, exclusivamente, os pensamentos de cachorros e ratos (n.442) ou as palavras de um futuro astronauta russo (n.443).

Em resposta, assinalou o editor: "Se o leitor verificar mais atentamente, poderá constatar que as reportagens referentes às conquistas espaciais por nós publicadas seguem um estrito critério de imparcialidade." ${ }^{20}$

Nos países industrializados da Europa e da América do Norte, a tecnologia desenvolvida para fins bélicos - energia nuclear, radar, mísseis tanto fortalecia o poder político e militar como era usada para acelerar o ritmo do crescimento da economia. Centralizadas, políticas científicas e tecnológicas passaram a ser formuladas, pretendendo a solução de múltiplos problemas dessas economias. Contudo, a disputa político-ideológica levava os governos soviético e americano a investir maciçamente na publicidade em torno dos avanços científicos em veículos de comunicação de massa de vários países. Manchete acompanhava diretamente esse processo por meio de contrato com as agências internacionais de notícia. Leon Eliachar, de forma satírica, remete ao tema:

O sputnik veio provar uma coisa: que em matéria de satélites ninguém pode 
competir com a Rússia. O Vanguard veio provar outra coisa: que em matéria de espaço tanto faz ao americano conquistar a ionosfera como o espaço de um jornal - ambos dão publicidade. O lançamento do Sputnik veio evidenciar que em matéria de astronáutica a ciência russa está mais adiantada do que a americana, o que evidentemente os fará chegar primeiro à Lua. Mas eu não ficarei surpreso se os russos chegarem à Lua e lá encontrarem espalhados cartazes por todos os lados: Sejam bem-vindos. Bebam Coca-cola. ${ }^{21}$

Já no Brasil a produção de conhecimentos científicos e de energia nuclear eram tidos como as soluções para superar o atraso crônico da nação e como forma de ostentar a grandeza cultural e o poder político-militar. Aqui, assim como lá, Exército e Marinha foram os primeiros a estreitar os vínculos com os produtores de ciência. Associavam a industrialização e os recursos naturais com política, emancipação econômica e soberania. A despeito da conseqüente emergência das armas nucleares ter quebrado o vínculo entre poder militar e poder econômico, as preocupações do Terceiro Mundo estavam em outro estágio ${ }^{22}$.

A aliança entre ciência e militares foi a principal responsável pelo aumento da produção científica. Do mesmo modo que não se pode inferir que os militares defendiam a utilização da energia nuclear na produção de eletricidade como mera estratégia técnica, é ingênuo supor que não tivessem interesse na tecnologia dos armamentos nucleares. Já os físicos - Cesar Lattes, Jayme Tiomno, Hugo Camerini, José Leite Lopes e Marcelo Damy, personalidades fotografadas pela Manchete - eram de uma geração em que a guerra condicionou as opções sociais, políticas e filosóficas. Queriam fazer ciência no país.

A publicidade em torno de Cesar Lattes - o físico mais citado - explicita a predisposição dos veículos de informação em selecionar arquétipos capazes de oferecer uma representação de suas áreas de atuação. Como os mitos do cinema e do esporte, a seleção dos eleitos na imprensa não é desinteressada mas depende das relações que se estabelecem entre

os campos sociais. No caso da ciência, entretanto, parece não funcionar da mesma forma, pois o próprio Lattes procurou - apesar de tê-la utilizado - desfazer sua imagem mítica quando não mais lhe interessava em 0 Cruzeiro.

Os critérios utilizados para eleger as dez mais elegantes do ano ou para escolher a mais bela atriz de cinema eram diferentes dos parâmetros empregados pela imprensa para identificar os cientistas mais produtivos. Na reportagem "61 o ano louco", Jaime Tiomno é o destaque do meio científico, pela contribuição à física teórica. Como o seu trabalho sobre o méson $\mathrm{K}$ foi considerado relevante pelos seus pares, a Manchete expli- 
cou aos leitores: "No campo da ciência, o professor Jaime Tiomno foi o Colombo do méson $\mathrm{K}$, e deu mais um título para o Brasil na empolgante aventura da era atômica. Outro cientista com destacada atuação este ano: Marcelo Damy". Assim, imprimindo a marca do sensacionalismo na divulgação da ciência, a revista ainda destacou que "Na ciência, nos esportes e na música popular surgiram caras novas. Mas Pelé continua Pelée'23.

\section{MANCHETE E O CRUZEIRO}

Considerando que Manchete e $O$ Cruzeiro eram periódicos semanais de circulação nacional dirigidos ao mesmo público leitor e que, em 1957, a soma da tiragem dos dois pode ser estimada em um milhão de exemplares - lidos, no mínimo, por duas pessoas de uma mesma família -, a comparação entre ambos é inevitável e imprescindível para as conclusões deste trabalho. Assim, como teriam influenciado um percentual significativo da população alfabetizada do país, a análise comparada da contribuição dos mesmos para o desenvolvimento do pensamento científico ajudaria a compreender as raízes históricas da fraca articulação entre ciência e sociedade. Com esta finalidade, foram selecionadas fotorreportagens sobre o mesmo cientista, informações quantitativas, temas comuns e algumas características editoriais que poderiam ter influenciado determinados comportamentos em relação à ciência e tecnologia identificados posteriormente.

A primeira grande reportagem de 0 Cruzeiro sobre um cientista brasileiro - "Cesar Lattes, o méson e a ciência no Brasil" - foi escrita em 1947 por Mário Camarinha, estudante de pós-graduação em literatura na Universidade da Califórnia e que havia se tornado amigo de Lattes em Berkeley. A fotorreportagem refletia as características da revista: leitura agradável, apelos emocionais, entre informações precisas sobre a carreira científica do físico; fotografias ocupando $100 \%$ de duas páginas e $80 \%$ de outras duas, nas quais Lattes aparece sozinho, fumando cigarros, na companhia de amigos e ao lado do próprio autor da matéria.

$\mathrm{Na}$ abertura, informava-se que o diretor do Radiation Laboratory de Berkeley (Universidade da Califórnia) anunciara a "mais de 40 repórteres americanos a descoberta de Lattes". Focalizando Lattes no primeiro plano, eram destacadas cuidadosamente a sua formação e produção científica, ao passo que Eugene Gardner - físico reconhecido e co-autor do trabalho anunciado à imprensa - apenas foi mencionado. Tal como a ideologia individualista do Prêmio Nobel, há muito tempo a falsa imagem do cientis- 
ta isolado em seu laboratório é construída. Ao tratar da participação de Cesar Lattes na detecção do méson-p, o píon, o Cruzeiro deslanchou o processo de heroificação do personagem, reforçando estereótipos:

Não é fácil fazer com que o cientista que é homem calado, de olhos perdidos no ar e justo de quem está com o pensamento longe (só o sorriso entre tímido e malicioso, aparecendo aqui e ali na conversação, nos dá certeza de que ele, ao contrário, sabe muito bem onde tem a cabeça) fale do assunto em que seu nome aparecerá de relevo. Fala pausadamente, calmo, tentando pôr em linguagem corrente esta história do méson. ${ }^{24}$

Para a opinião pública, Cesar Lattes era a grande estrela da ciência no Brasil. E ele se prestou ao papel reservado pelo 0 Cruzeiro e Manchete porque, além de ter dado efetiva contribuição ao desenvolvimento da ciência, precisava sensibilizar a sociedade para a obtenção de mais recursos para o Centro Brasileiro de Pesquisas Físicas. Na revista Manchete, o jornalista Joel Silveira parecia estar de uma janela descortinando o morro de Chacaltaya e as dificuldades enfrentadas por Lattes para a montagem de um laboratório de física cósmica na Bolívia. "O Brasil quase vence César Lattes” era uma descrição primorosa da sua trajetória científica, de 1946 até 1955, sem precisar recorrer a analogias e imagens fáceis. A matéria, publicada numa conjuntura política particular - após o suicídio de Vargas e as denúncias de desvio de verbas do Projeto do Sincrociclotron -, oferecia ao leitor informações para a compreensão dos problemas do CBPF e sobre a utilização pacífica da energia nuclear. Se as opiniões no meio acadêmico se dividiram, Joel Silveira foi um porta-voz do grupo de Lattes, sem precisar glorificar o cientista, mesmo na chamada da fotorreportagem:

No momento em que se instala no Rio o simpósio da física nuclear brasileira, a reportagem que se segue ganha oportunidade e interesse. Ela conta a história de um grupo de jovens pesquisadores, comandados por um cientista cheio de fé, Cesar Lattes, e por um homem idealista e corajoso, João Alberto, empenhados todos na criação, no Rio, de uma entidade a serviço da pesquisa e do estudo. Esse grupo, lutando contra todas as dificuldades, conseguiu realizar o seu sonho. Adiante se conta isso e de como a indiferença e a frivolidade nacionais não conseguiram matar o que hoje é uma magnifica realidade no panorama científico do país: o Centro Brasileiro de Pesquisas Físicas. ${ }^{25}$

Prosseguindo nessa linha editorial, a Manchete não teria contribuído 
para aprofundar as diferenças entre cientistas e os cidadãos comuns. Contudo, os títulos e legendas da última reportagem sobre Lattes - "A volta do gênio atômico", "Uma explosão interior derrubou o gênio" e "O verdadeiro homem de ciência é antes de tudo um solitário"- são suficientes para exemplificar que a Manchete trocara o investimento em educação científica pelo caminho fácil e percorrido, com sucesso, pelo 0 Cruzeiro, com a finalidade de atrair leitores.

O Quadro 2 reflete as preocupações existentes na sociedade brasileira entre cientistas, militares, políticos e técnicos do governo, e a atenção dada pelas principais revistas de entretenimento. A produção de energia nuclear, a bomba atômica e a exploração dos minerais físseis faziam parte das discussões nacionais, travadas em vários planos da política brasileira: no Congresso Nacional, nas associações militares e de profissionais liberais, e nos eventos científicos das áreas de física, geologia, biofísica e química. Mesclando o discurso de especialistas e o discurso jornalístico para o público leitor se sentir atualizado, as revistas se apropriavam de palavras do campo científico e incluíam as mesmas na linguagem cotidiana dos brasileiros: "Um conto de fadas na idade atômica"; "Trens atômicos no metrô carioca"; "Criatura tradicionalmente atômica, Rita (Gilda) Hayworth veio de longe para explodir no carnaval carioca (...)” e, como mencionado, "A volta do gênio atômico".

Quadro 2 - A física e a produção de energia nuclear

(n. ${ }^{\circ}$ de matérias)

\begin{tabular}{lcccccccccc}
\hline ANO & \multicolumn{2}{c}{ FÍSICA } & \multicolumn{2}{c}{ BOMBA } & \multicolumn{2}{c}{ ENERGIA } & \multicolumn{2}{c}{ MINERAIS } & \multicolumn{2}{c}{ TOTAL } \\
\hline & Manh & Guz & Mand & Guz & Mand & Guz & Mand & Guz & Mand & Guz \\
\hline 1952 & 3 & & 1 & 5 & & 1 & & & 4 & 6 \\
\hline 1953 & 1 & 2 & 2 & 8 & & 1 & 2 & 1 & 5 & 12 \\
\hline 1954 & 3 & 3 & 4 & 8 & 3 & 8 & & & 10 & 19 \\
\hline 1955 & 11 & 3 & 6 & 8 & 2 & 8 & 1 & & 20 & 15 \\
\hline 1956 & 3 & 1 & 5 & & 1 & 5 & 3 & 3 & 12 & 9 \\
\hline 1957 & 3 & 3 & 4 & 4 & & 4 & 4 & 2 & 11 & 13 \\
\hline 1958 & 6 & 4 & 1 & 6 & 10 & 6 & 2 & & 19 & 17 \\
\hline 1959 & 5 & 2 & 2 & 7 & 3 & 7 & & & 10 & 12 \\
\hline 1960 & 3 & 1 & 3 & 2 & 1 & 2 & 2 & 1 & 9 & 7 \\
\hline 1961 & 6 & 3 & 11 & 4 & 5 & 4 & & & 22 & 8 \\
\hline 1962 & 5 & & 9 & 6 & 1 & 6 & & & 15 & 10 \\
\hline Total & 49 & 22 & 48 & $\mathbf{5 8}$ & $\mathbf{2 6}$ & $\mathbf{5 0}$ & $\mathbf{1 4}$ & $\mathbf{7}$ & $\mathbf{1 3 7}$ & $\mathbf{1 3 7}$ \\
\hline
\end{tabular}

Fonte: O Cruzeiro e Manchete. Rio de Janeiro, 1952-62 
Era usual utilizar esses periódicos para criticar a omissão do Estado e o descaso dos governos com os institutos de pesquisa do Brasil. No caso de 0 Cruzeiro, incitava-se o confronto Brasil/Argentina ao comparar o desenvolvimento das ciências nucleares e de suas aplicações entre os dois países. E, no contexto da Guerra Fria, desenvolver as ciências nucleares não significava somente construir reatores e centrais termonucleares para obtenção de energia elétrica e, indiretamente, produzir armamentos que utilizam plutônio. Significava impulsionar um conjunto de atividades ligadas à produção e aplicação do conhecimento científico - geologia, química, física e engenharias e utilizar isótopos na agricultura, medicina e biologia, etc. - e desenvolver indústrias, como a metalúrgica e a eletrônica.

As matérias sobre a aparição de discos voadores, fenômeno que permeou o imaginário das sociedades urbanas, notadamente no período que antecedeu as primeiras viagens espaciais, eram comuns às revistas. Em ambas, havia espaço para notícias de anúncios de viagens à Lua promovidas por agências americanas, dentre outras notícias e fotografias de fontes duvidosas. Talvez a Manchete, por não se interessar pela chamada subliteratura de ficção - em seu lugar, introduziu as famosas crônicas de escritores que comentavam o cotidiano das grandes cidades -, não fizesse montagens fotográficas. Publicou-se na Manchete, no entanto, uma série de reportagens sobre viagens interplanetárias e mundos extraterrestres sob o título "O homem e o espaço", de Carlos Eiras. Nela se identificou ingenuidade na noção de tempo e incorreções:

Há 20 séculos o homem trabalha, estuda, planeja e constrói foguetes, sem cessar. Se, no ano 1 de nossa era, a preocupação era construir um engenho capaz de queimar alguns adversários, hoje em dia a preocupação são os teleguiados que atravessem continentes e cheguem, o mais cedo possível, à Lua. ${ }^{26}$

Fotorreportagens sobre a tentativa de alunos da Escola Técnica do Exército, que sonharam fabricar e lançar o "Félix I", um foguete nacional tripulado por um gato chamado Flamengo, saíram nas duas revistas em 1958 e 1959. "Gato sideral verde-amarelo", da Manchete, e O "Foguete Miau", para 0 Cruzeiro, deixaram hilárias seqüelas. Com vistas à obtenção do necessário respaldo científico para reproduzir no Brasil as experiências radiobiológicas por que passou a cadela russa Laika, usaram o nome do biofísico e professor Carlos Chagas Filho. O foguete de pólvora não decolou e Carlos Chagas Filho também fez duras críticas ao projeto $^{27}$. 
Se na conjuntura dos anos de 1950, uma significativa parcela da sociedade estava interessada na discussão de questões nacionais - exploração do petróleo e minerais - os periódicos tinham necessidade de noticiar, inclusive, o desenvolvimento das pesquisas nessas áreas. As reportagens, consequentemente, não apenas informavam os acontecimentos científicos realizados em laboratórios estrangeiros e nacionais, como criavam expectativas de um novo mundo que se configurava baseado no poder da ciência.

Mesmo havendo expressivas diferenças na abordagem da ciência durante o período analisado, ambas, Manchete e $O$ Cruzeiro divulgavam a ciência valendo-se da imagem na construção do discurso jornalístico. Contribuindo para tornar de conhecimento do público leitor - ainda que de forma restrita - a ciência e suas aplicações, as distintas fotorreportagens demonstram como as opções editoriais mesclam saberes, práticas e poderes distintos.

Divulgando a idéia de que a ciência era sempre grandiosa, abstrata e inacessível ao cidadão comum, dando lugar a um universo de mitos, de cientistas isolados e solitários em complexos laboratórios, não favoreceu a predisposição para que brasileiros fizessem ciência. Ao erigir uma mu262 ralha entre o cientista e o leitor, ao mitificar ou banalizar a atividade científica, as revistas estabeleceram falsas premissas de como a ciência é construída.

Da mesma forma, a idealização do homem e da mulher de ciência forjada nos noticiários podem resultar numa mitificação do trabalho científico e distanciamento entre ciência e sociedade. Uma supervalorização da ciência e do cientista pouco contribui para o desenvolvimento de pesquisas para o bem estar social. Esta visão deturpada faz a ciência inatingível e o cientista alguém fora dos padrões dos grupos sociais.

Hoje se sabe que a propaganda e a divulgação de idéias são fundamentais para o estabelecimento de projetos hegemônicos e ideológicos, assim como para a construção de identidades e senso comum. No estudo realizado, não é possível mensurar a influência do jornalismo na alfabetização científica, apenas opinar que Manchete e $O$ Cruzeiro tiveram influências distintas na formação de uma mentalidade científica, ao longo de um curto período da História da Ciência no Brasil. E, sem reforçar estereótipos de gênero, pelo contrário, valorizando a atuação de mulheres cientistas nas diversas áreas do conhecimento - inclusive as atividades da historiadora Maria Yeda Linhares -, a Manchete venceu a sua concorrente $O$ Cruzeiro. 


\section{NOTAS:}

* Registram-se os agradecimentos a Vera Gertel e Francisco de Assis Barreto, que possibilitaram a consulta no Arquivo da Manchete, a Sérgio Eiras, da biblioteca da ABI, e a colaboração de Fernanda Kischinhevsky (bolsista IC /CNPq) no levantamento de dados.

${ }^{1}$ ALVES, Isidoro. Modelo politécnico, produção de saberes e a formação do campo científico. In: HAMBURGUER, A., Dantes, M. A., PATY, M., PETITJEAN, P. (org.). A ciência nas relações Brasil-França (1850-1950). São Paulo: Edusp/ Fapesp, 1996.

${ }^{2}$ ANDRADE, Ana Maria Ribeiro de. Físicos, mésons e política: a dinâmica da ciência na sociedade. São Paulo e Rio de Janeiro: Hucitec/MAST, 1999, capítulo 4. . A construção de um mito da ciência. Perspicillum. Rio de Janeiro: MAST, v. 8, n.1, pp.107-137, nov. 1994.

${ }^{4}$ Idem, pp.111-119.

${ }^{5}$ MASSARANI, Luisa. A divulgação científica no Rio de Janeiro: algumas reflexões sobre a década de 20. Rio de Janeiro: 1998. [dissertação de mestrado, ECO - UFRJ]; GOUVEA, Guaracira. A divulgação da científica para crianças: o caso da Ciência Hoje para crianças. Rio de Janeiro: 2000 [tese de doutorado, Instituto de Biofísica - UFRJ].

${ }^{6} I d e m$, anexo. CAZELLI, Sibelli. Alfabetização científica e processos educativos. Perspicillum. Rio de Janeiro: : MAST, v. 6, n.1, 1992, pp. 75-104.

${ }^{7}$ BOURDIEU, Pierre. Sobre a televisão: seguido de a influência do jornalismo e os jogos olímpicos. Rio de Janeiro: Zahar, 1997.

${ }^{8}$ BLOCH, Adolpho. De Kiev ao Rio. Manchete. Rio de Janeiro: ed. especial, pp. 242-253 e 256, nov. 1997.

${ }^{9}$ Idem, p. 249 .

${ }^{10}$ MANCHETE. Rio de Janeiro: n. 337, pp. 4-5, out. 1958.

${ }^{11}$ BIELSCHOWSKY, Ricardo. O pensamento econômico brasileiro: o ciclo ideológico do desenvolvimentismo. Rio de Janeiro: IPEA/INPES, 1988.

${ }^{12}$ MANCHETE. Rio de Janeiro: n. 146, p. 3, 5 fev. 1955.

${ }^{13}$ ANDRADE, op. cit., 1999, capítulo 4.

${ }^{14}$ EKSTEINS, Madris. A sagração da primavera. Rio de Janeiro: Rocco, 1991.

${ }^{15}$ GOMES, Isaltina M. A. Dos laboratórios aos jornais: um estudo sobre o jornalismo científico. Recife: 1995 [dissertação de mestrado, UFPE].

${ }^{16}$ MANCHETE. Rio de Janeiro: n. 6, pp.1, 4-7 e 19-22, 31 maio 1952; Idem., n. 7, pp.2730 e 36-7, 7 jun. 1952; Idem., n. 8, p. 38, 14 jun. 1952.

${ }^{17}$ MANCHETE. Rio de Janeiro: n. 11, pp. 15-75, jul. 1952; Idem, n.14, p.3, 26 jul. 1952; 
Idem., n. 15, p. 38, 2 ago. 1952; Idem., n. 17, pp.18-9, 16 ago. 1952; sobre o evento citado, ANDRADE. op. cit., 1999. pp. 135-137.

${ }^{18}$ MANCHETE. Rio de Janeiro: n. 475, 27 maio 1961, p. 75; Idem., n. 457, pp. 90-95, 21 jan. 1961, Idem, n. 56, pp. 24-25, 16 maio 1953.

${ }^{19}$ MANCHETE. Rio de Janeiro: n. 486, pp. 10-18, 12 ago. 1961.

${ }^{20}$ MANCHETE. Rio de Janeiro: n. 447, p.4, 12 de novembro de 1960.

${ }^{21}$ MANCHETE. Rio de Janeiro: n.290, p. 87, 9 de novembro de 1957.

${ }^{22}$ ANDRADE. op. cit., 1999, capítulo 2.

${ }^{23}$ MANCHETE. Rio de Janeiro: n.506, pp. 97-102, 30 dez 1961. Ver também em MANCHETE. Rio de Janeiro: n.460, p.66, 11 fev. 1961, a matéria sobre Cesar Lattes intitulada "A volta do gênio atômico".

${ }^{24}$ O CRUZEIRO. Rio de Janeiro: n. 29, p.36, 8 de maio de 1948.

${ }^{25}$ MANCHETE. Rio de Janeiro: n.151, p. 6, 12 de março de 1955.

${ }^{26}$ MANCHETE. Rio de Janeiro: n. 294, p.80, 7 de dezembro de 1957.

${ }^{27}$ MANCHETE. Rio de Janeiro: n.342, pp. 16-18, 8 nov. 1958; Idem, n.343, p.28-30, 15 nov. 1958; Idem, n.344, p.133, 22 nov. 1958; O CRUZEIRO. Rio de Janeiro: ano 31, n.12, pp.20-5, 3 jan. 1959; idem, ano 32, no 1, p. 56, 17 out. 1959. 